\title{
Hebeloma alvarense, a new species from Estonia
}

\author{
JAN VESTERHOLT and JUKKA VAURAS
}

VESTERHOLT, J. \& VAURAS, J. 2004: Hebeloma alvarense, a new species from Estonia. - Karstenia 44: 57-60. 2004. Helsinki. ISSN 0453-3402.

Hebeloma alvarense Vesterh. \& Vauras (Basidiomycota, Agaricales) is described as a new species from open alvar pine forest of Western Estonia. It belongs to the section Denudata (Fr.) Sacc., and it is characterized macroscopically by a cinnamon-coloured pileus and a very fragile, floccose stipe.

Key words: Agaricales, Estonia, Hebeloma, taxonomy

Jan Vesterholt, Botanical Museum, Gothersgade 130, DK-1123 Copenhagen K, Denmark

Jukka Vauras, Biological Collections of Åbo Akademi University, Herbarium, FI-20014 University of Turku, Finland

\section{Introduction}

A special habitat type known as alvar has developed on limestone areas, especially on the coast and islands of Estonia, as well as on the islands Öland and Gotland of Sweden. Different types of alvar habitats include alvar forests, alvar shrublands, alvar grasslands and alvar heaths. They are characterized by a thin mineral soil layer upon limestone or calcareous gravel. The productivity is relatively low, mainly because of the lack of moisture. The fungus flora of the alvars is very interesting. In these areas several fungi are found, which have never been found in Finland, e.g. Cortinarius terpsichores Melot, Entoloma bloxamii (Berk. \& Broome) Sacc., E. incanum (Fr. : Fr.) Hesler, E. roseum (Longyear) Hesler and Hygrocybe calciphila Arnolds.

During the stay of the second author in Hiiumaa island, participating in the Estonian-Finnish Workshop on Fungal Taxonomy on 12-18 Sept. 2001 , the fungus season in the area was excellent. A very distinctive Hebeloma was found in an open pine forest in the southern part of Hiiumaa,
Estonia. Even in the field the species was eyecatching being cinnamon, distinctly zoned, and having broad lamellae and a very fragile stipe. Later, it was found to have a combination of characters, which do not match any of the known species of the genus.

Microscopical characters were measured and drawn in $5 \% \mathrm{KOH}$. The quantitative values D1, D4, O3, P2 used for spore characters in this paper refer to Vesterholt (1995). The colour code refers to Kornerup and Wanscher (1978) and HeilmannClausen et al. (1998).

Hebeloma alvarense Vesterh. \& Vauras, species nova

Figs. 1-2

Pileus 1.3-3.8 cm latus, convexus, deinde expansus, cinnamomeus, zonatus. Lamellae usque ad $7 \mathrm{~mm}$ latae, ventricosae, emarginatae, satis distantes, pallide brunneae, guttis aqueis siccae maculatae. Stipes 3.0-3.8 cm longus, 3-6 mm 
crassus, cylindraceus, floccosus, albidus, fragilissimus. Cortina nulla. Velum non observum. Odore raphanino. Sporae 11.0-14.0 × 5.5-7.5 $\mu \mathrm{m}$, ex maxima parte anguste amygdaliformes vel fusiformes. In solo calcareo.

Holotypus: Estonia. Hiiumaa. Käina commune, Kassari, Sääre, camping place, open alvar forest with Pinus sylvestris and Juniperus communis, on calcareous soil, alt. ca. $5 \mathrm{~m}, 17 . I X .2001 \mathrm{~J}$. Vauras $17955 F(\mathrm{C}$; isotypes in $\mathrm{H}$, TAA, TUR).

Pileus 13-38 mm broad, convex to expanded, not umbonate, margin even or slightly crenulate, surface smooth, nearly dry, almost unicoloured cinnamon (6C5-6), very pale brown at the extreme margin, with innate greyish brown fibrils and a narrow, greyish brown ring-zone at half the radius. Lamellae deeply emarginate, fairly distant, ventricose, broad to very broad, up to $7 \mathrm{~mm}$, lamellulae abundant, clay-buff, edge uneven, whitish, with small droplets, later spotted from these. Stipe 30-38 × 3-6 mm, cylindrical, not distinctly widened at base, not rooting, floccose in the entire length, whitish to greyish white, tinged pinkish buff at base, very fragile. Cortina absent. Uni- versal veil not seen. Smell raphanoid. Exsiccatae not blackened.

Spores 11.0-14.0 $\times 5.5-7.5 \mu \mathrm{m}$, on average 12.4 $13.3 \times 6.1-6.7 \mu \mathrm{m}$ (four fruitbodies, each 25 spores), narrowly amygdaliform to amygdaliform or fusiform, a large majority narrowing towards the apiculus, often with apical papilla, $\mathrm{Q}=1.70-2.15$, on average 1.88-2.06; ornamentation very distinct (O3), perispore loosening in many spores (P2), dextrinoid reaction weak (D1). Basidia 25-32 $\times$ 8.5-10 $\mu \mathrm{m}$, cylindrical to clavate, 4-spored. Cheilocystidia $28-65$ m long, $6-9(-10) \mu \mathrm{m}$ wide at apex, 4-5 $\mu \mathrm{m}$ wide in the median part, 4-11 $\mu \mathrm{m}$ wide near the base, clavate, often also widened in the lower part, a minority ventricose with a cylindrical apical part, apex on average $7.2 \mu \mathrm{m}$ wide $(n=$ 25), hyaline, thin-walled or somewhat thick-walled in the apical part. Pleurocystidia not observed. Gill trama hyaline to very pale brownish. Pileipellis an ixocutis; epicutis about $20-30 \mu$ m thick, enclosed hyphae $2-5 \mu \mathrm{m}$ broad, encrusted, hyaline to brownish; cutis of dark reddish brown elements with encrusting pigment.

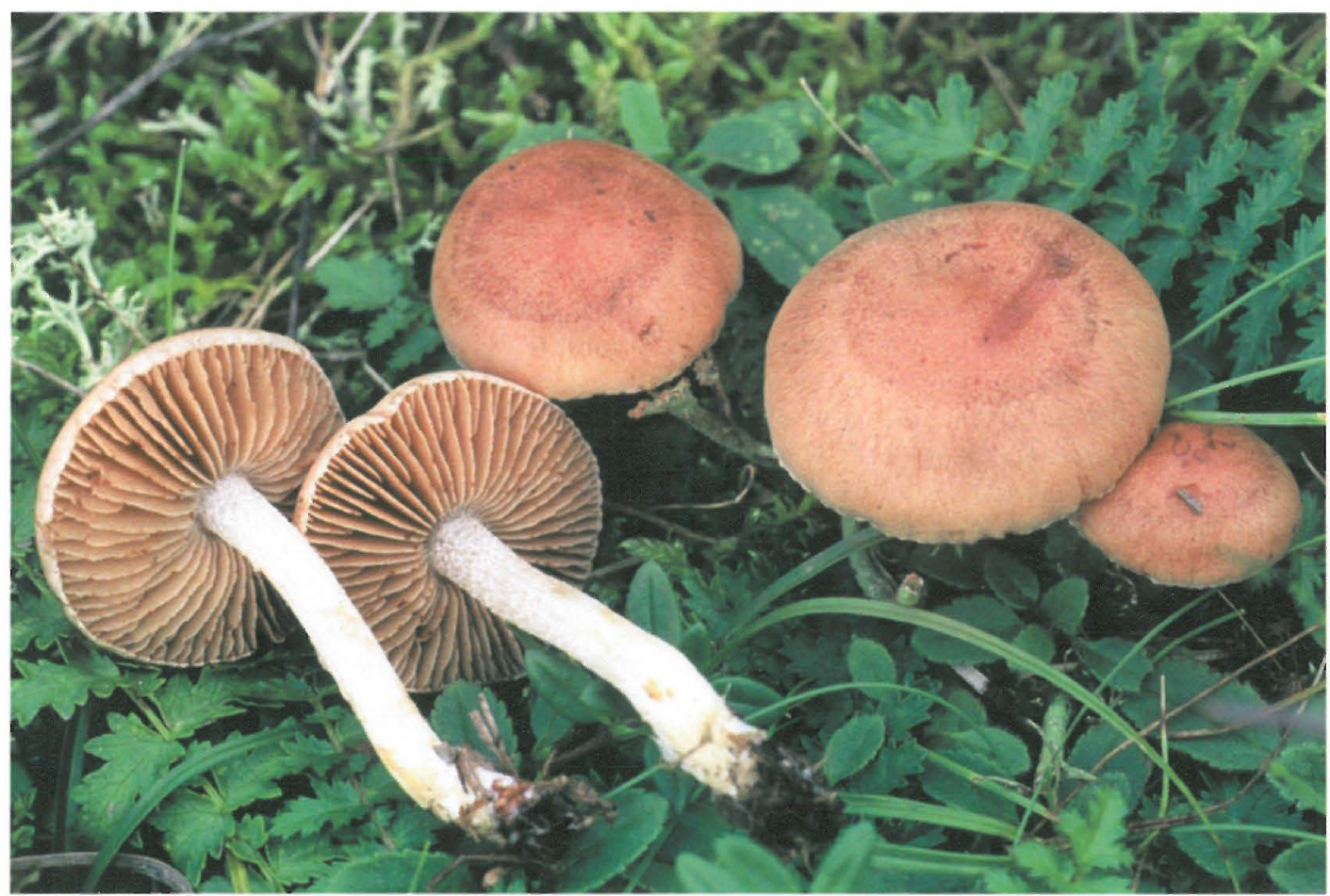

Fig. 1. Hebeloma alvarense Vesterh. \& Vauras, in situ. Type, $\times$ approx. 1.2, photograph Jukka Vauras. 


\section{Ecology}

Hebeloma alvarense is only known from the type collection, which was found in open alvar forest with Pinus sylvestris and Juniperus communis. The type locality has been used as a natural camping area, but not too intensively. The site is characterized by a low vegetation of lichens and vascular plants, e.g. Filipendula vulgaris, Thymus serpyllum, Helianthemum nummularium, Plantago lanceolata, and Antennaria dioica. Agar- ics found in the type locality include Inocybe in odora Velen., I. oblectabilis (Britzelm) Sacc., Hebeloma senescens (Batsch) Berk. \& Broome and Russula sanguinea (Bull.) Fr., all mycorrhizal species with Pinus sylvestris, and species characteristic of Juniperus alvars, viz. Entoloma catalaunicum (Singer) Noordel., E. excentricum Bres., Lepiota alba (Bres.) Sacc., and L. oreadiformis Velen. Volvariella pusilla (Pers. : Fr.) Quél. was also collected.

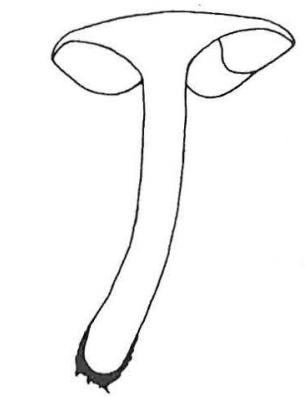

a

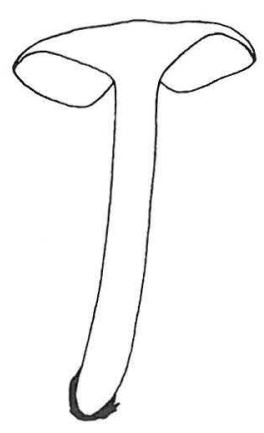

$1 \mathrm{~cm}$
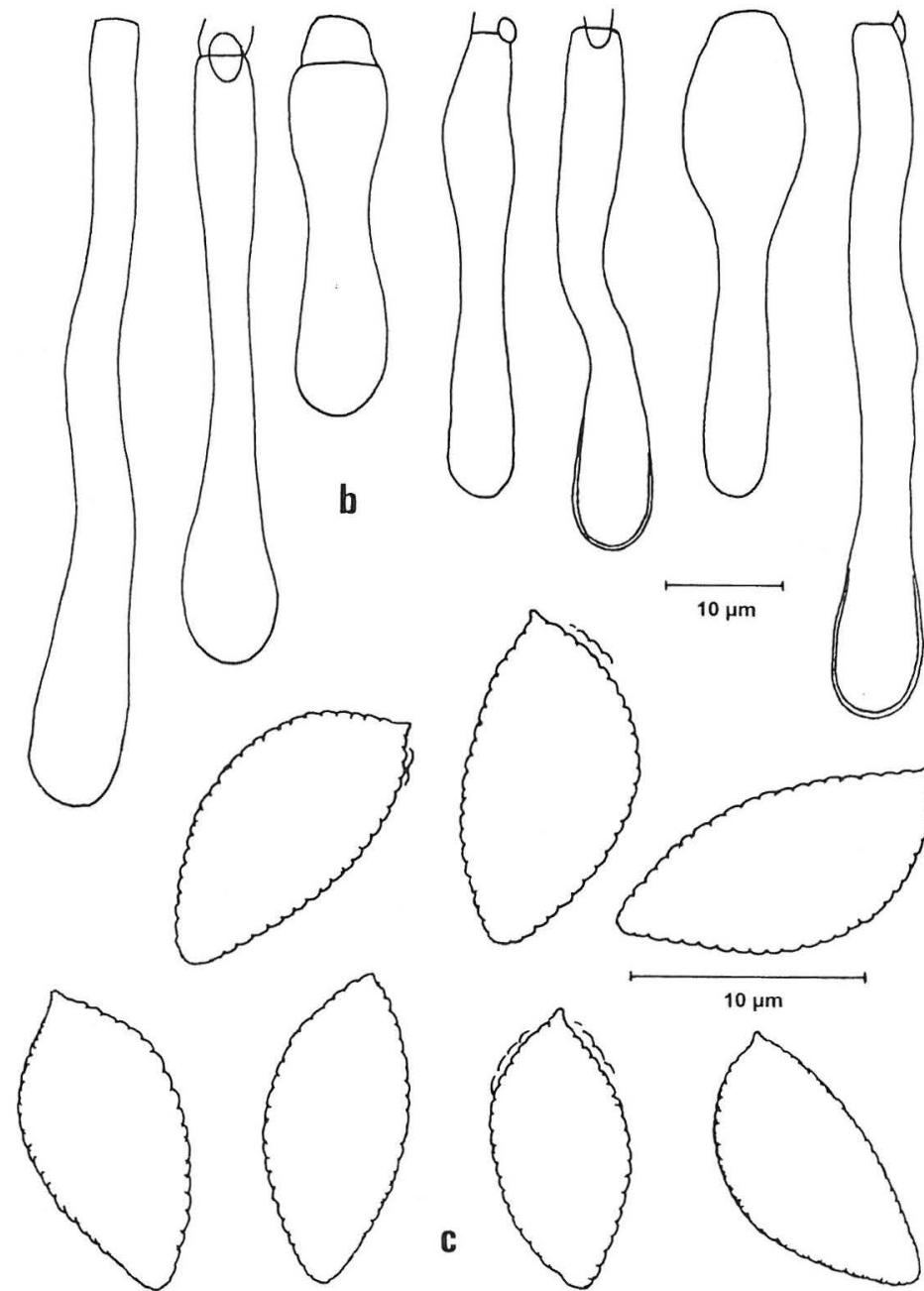

$10 \mu \mathrm{m}$

\section{.}




\section{Discussion}

With the droplets formed on the gills, the raphanoid smell, the non-rooting stipe, the strongly ornamented spores and the clavate cheilocystidia, Hebeloma alvarense is a member of section Denudata, which is typified with $H$. crustuliniforme (Bull.) Quél. The outstanding characters of $H$. alvarense are the cinnamon coloured pileus, the broad and fairly distant lamellae, the fragile stipe, the very thin epicutis and the more or less fusiform spores with a loosening perispore. The zonation of the pileus may also prove to be a useful character to delimit the species, but until more material has been studied it is impossible say whether this character is constant.

The fragile stem and the slightly dextrinoid spores with a loosening perispore are also found in Hebeloma fragilipes Romagn., but that species has a much paler cap, and a much thicker epicutis, generally around $100 \mu \mathrm{m}$. For a description of H. fragilipes, see Romagnesi (1965) and Vesterholt $(1995,2000)$. In the type material of $H$. fragilipes the cystidia often have thickened walls in the median part. This feature has not been observed in $H$. alvarense. It should be noted that $H$. fragilipes and $H$. hiemale Bres. belong to a species complex that is not yet fully understood, and which probably includes several species varying in a number of characters such as colour, size and spore features. For a description of original material of $H$. hiemale, see Grilli (1997).

The only known species from Europe combining \pm fusiform spores and a very thin epicutis is Hebeloma cremeopallidum (Esteve-Rav. \& Heykoop) Esteve-Rav. \& Heykoop (Esteve-Raventós \& Heykoop 1990, Heykoop \& Esteve-Raventós 1997). Until now it is only known from Spain, and it differs from $H$. alvarense in having a pale cap and longer spores, $12.5-15(-17) \times 6-7 \mu \mathrm{m}$, on average $14.3 \times 6.6 \mu \mathrm{m}(\mathrm{n}=20$, own observations $)$, with a strong dextrinoid reaction (D4).
Due to the cinnamon colour, Hebeloma alvarense may superficially resemble $H$. theobrominum Quadr. or H. birrus (Fr.) Gillet. The former has smaller spores with a non-loosening perispore and a strong dextrinoid reaction, while the latter has a fruity smell, short, \pm cylindrical cheilocystidia and spores with a strong dextrinoid reaction. In addition, both of these species have a thicker epicutis than $H$. alvarense, and none of the aforementioned species has broad lamellae or droplets on the lamellae.

Acknowledgements: We are indebted to Henry Beker and Seppo Huhtinen for critical reading of the manuscript, to Pia Boisen Hansen for assistance with the drawings, and to Ernest Emmett for linguistic improvements.

\section{References}

Esteve-Raventós, F. \& Heykoop, M. 1990: Notas micológicas. I. Hebeloma vaccinum Romagn. y Hebeloma vaccinum var. cremeopallidum var. nov. - Cryptogamie Mycol. 11: 21-29.

Grilli, E. 1997: Ridescrizione dei caratteri micromorfologici di Hebeloma hiemale. - Bolletino del Gruppo Micologico G. Bresadola - Nuova serie. BGMB 40: 251-260.

Heilmann-Clausen, J., Verbeken, A. \& Vesterholt, J. 1998 : The genus Lactarius. - Fungi of Northern Europe 2: $1-287$.

Heykoop, M. \& Esteve-Raventós, F. 1997: Mycological notes, II. Neotypification of Hebeloma cistophilum, a Mediterranean pleurocystidiate species, and combination of Hebeloma cremeopallidum (Esteve-Rav. \& Heykoop) comb. nov. - Mycotaxon 61: 209-213.

Kornerup, A. \& Wanscher, J.H. 1978: Methuen handbook of colour. $3^{\text {rd }}$ ed. - Methuen, London.

Romagnesi, H. 1965: Etude sur le genre Hebeloma. Bull. Soc. Mycol. France 81: 321-344.

Vesterholt, J. 1995: Hebeloma crustuliniforme and related taxa - notes on some characters of taxonomic importance. - Acta Univ. Ups. Symb. Bot. Ups. 30: 129-137.

Vesterholt, J. 2000: Hebeloma crustuliniforme and related species. - Field Mycology 1: 58-68. 